\title{
Description of Lutzomyia chotensis, a new species of Peruvian Phlebotominae (Diptera, Psychodidae)
}

\author{
Eunice A. Bianchi Galati ${ }^{1}$ \\ Abraham G. Cáceres ${ }^{2}$ \\ Victor Zorrilla ${ }^{3}$
}

\begin{abstract}
Aвstract. Lutzomyia chotensis sp. nov. (Diptera, Psychodidae, Phlebotominae) from Cajamarca Department, Peru, is described and its taxonomic position discussed.
\end{abstract}

KEYwords. Lutzomyia chotensis sp. nov.; Phlebotominae; Psychodidae; taxonomy.

\section{INTRODUCTION}

In order to identify vectors of human bartonellosis and leishmaniases, sand fly captures were carried out in several provinces in the Región Nororiental del Marañón and resulted in 13 species (CÁCEREs et al. 1995), five of which described as new (GALATI \& CÁCERES 1994; GalatI et al. 1995a,b). In 1994, the captures also covered the province of Chota, where a single male of a new species was found, but it was damaged during maceration. After this, several attempts for capture were undertaken in this area but no other specimen of this taxon was captured. Despite the lack of some morphological structures it was decided to describe it because, possibly, it represents an intermediate taxon between Lutzomyia (Helcocyrtomyia) Barretto, 1962 and the other subgenera of Lutzomyia França, 1924, in accordance with GALATI's (1995) classification.

\section{MATERIAL AND METHODS}

The specimen, after maceration by the method given by FoRATTINI (1973) and mounted on microscope slides in NC medium (CERQUeIRA 1943), was measured with a Zeiss $®$ eyepiece calibrated with a standard Zeiss ${ }^{\circledR}$ scale and drawn with the help of an Olympus ${ }^{\circledR}$ drawing attachment. The specimen was captured with a CDC trap (SUDIA \& CHAMBERLAIN 1962) installed in a bedroom, from 4:00 pm to 6:00 am. The structural terminology, generally, follows McAlpine (1981), but for some specific structures studied in phlebotomines (ventrocervical sensillae, setae on the anterior edge of katepisternum and labial sutures) it follows GALATI (1995). The measurements are given in micrometers. The type will be deposited in the entomological collection of the Instituto Nacional de Salud, Lima, Peru (INSL).

\section{Lutzomyia chotensis sp. nov.}

(Figs. 1 - 6)

Male. Holotype. Total body length $c a$. 2,800. Coloration pale brown.

Head (Fig. 1): length 438, width 340. Ratio length/width 1.29. Eye length 178; width 100 (frontal view); ratio between lengths: eyes/head 0.41. Interocular distance 130. Interocular sutures not united with the interantennal suture. Clypeus 160; ratio between the lengths: clypeus/head 0.365 . Palpomeres: I 50, II 173, III, IV, V are missing. Antennomere lengths: AIII 392, with the external ascoid implanted more apically than the internal one; AIV damage, with simple and short ascoids (Fig. 2); AVAXVI missing. Labrum-epipharynx (LE) 300 long; AIII/LE 1.32. Cibarium (Fig. 3): anterior and posterior teeth absent, pigment patch conical and well developed, arch incomplete.

Ventrocervical sensillae present.

Thorax: length 660. Pleura with 3 proepimeral and 9,11 upper anepisternal bristles. Setae on the anterior edge of

\footnotetext{
1. Departamento de Epidemiologia, Faculdade de Saúde Pública, Universidade de São Paulo. Av. Dr. Arnaldo 715, 01246-904 São Paulo-SP, Brazil. E-mail: egalati@usp.br

2. Instituto Nacional de Salud, Calle Capac Yupanqui, 1400, Lima 100, Peru and Instituto de Medicina Tropical "Daniel A. Carrion", Universidad Nacional Mayor de San Marcos, Lima, Peru. E-mail: acaceres31@ hotmail.com

3. Faculdad de Ciencias Biológicas, Universidad Mayor de San Marcos, Lima, Peru.
} 

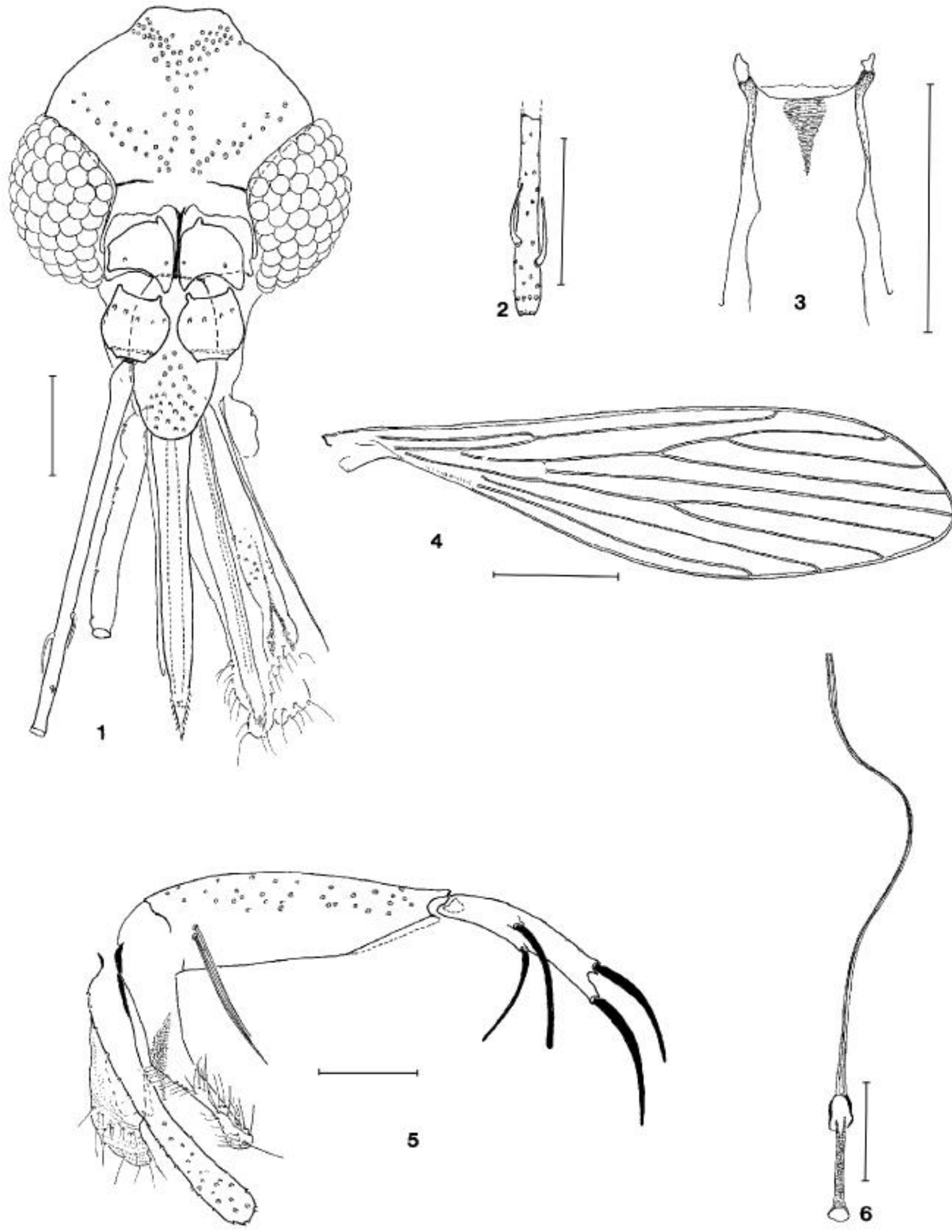

Figs. 1-6. Lutzomyia chotensis sp. nov., holotype, male. 1, head; 2, antennomere IV; 3, cibarium; 4, wing; 5, terminalia; 6, genital pump and filaments. Scales: wing $=500 \mu \mathrm{m}$; other figures $=100 \mu \mathrm{m}$. 
katepisternum absent. Wing (Fig. 4): length 2504, width 706, alpha 640, beta 260, gamma 440, delta 190 and pi 70.

Abdomen. Tergites V-VII with tergal papillae. Terminalia (Fig. 5): gonostyle 183 long, without the subterminal seta, 4 strong spines in the following positions: 1 apical, the upper external subapical, the lower external implanted before the middle and the internal in the middle of the structure. Gonocoxite 303 long, 85 wide, with a basal tuft with two straight setae and absence of the basal sclerotized ridge on the ventral margin. Paramere: dorsal margin length 182 and ventral margin length 234; with the basal part rectangular and the apical one digitiform, having a slightly thicker tip and concavity in the middle part of the dorsal margin; the digitiform area is covered by setae. Aedeagus: conical, dorsal margin length 86 and the ventral margin length 52. Lateral lobe 151 long, 26 wide at the middle of the structure and rounded tip. Genital pump 128 long, piston 100 long and chamber length 35 . Filaments 488 long or $3.81 \mathrm{x}$ the length of the genital pump (Fig. 6); tips of filaments simple. Cercus 195 long.

Holotype male. PERU, Cajamarca, Chota province, Paccha district, Matibamba (1900 m a. s. 1.), 10/11.X.1994. A. G. Cáceres col. (INSL).

\section{TAXONOMICDISCUSSION}

After the classification of THEODOR (1948), almost all taxonomists who have studied the American phlebotomines (except for a few species of Warileya Hertig, 1948, Hertigia Fairchild, 1949 and Brumptomyia França \& Parrot, 1921) included all other species in the genus Lutzomyia França, 1924 (BARRETTO 1962; THEODOR 1965; Lewis et al. 1977; MARTINS et al. 1978; Young \& DunCan 1994). However, in the phylogenetic classification proposed by Galati (1995) this genus is only composed by four subgenera: L. (Helcocyrtomyia) Barretto, 1962, L. (Castromyia) Mangabeira, 1942, L. (Lutzomyia), s. str. and L. (Tricholateralis) Galati, 1995. This last has L. cruciata as its type species. Lutzomyia, according to GaLATI (1995), presents papilla on the antennomere V (AV) (except Tricholateralis) and ventrocervical sensillae; on the palpomere III, Newstead's spines are situated together on the middle of the structure or dispersed on the segment, including the apical part, in both sexes. In males, the number of apical spines on the gonostyle is variable, the tip of the lateral lobe is rounded and the gonocoxite does not present a basal sclerotized ridge on the ventral margin; in the females, the spermathecae are annulated. In all other subgenera, excepting $L$. (Helcocyrtomyia), the setae on the anterior edge of katepisternum are absent.

The characteristics of $L$. chotensis sp. nov.: absence of setae on the anterior edge of the katepisternum, simple paramere without distinct isolated setae and gonostyle with one apical spine without subterminal seta, the lower external spine implanted before the middle and the internal spine in the middle of the structure, show its closer affinity with the subgenus $L$. (Tricholateralis). However, one of the synapomorphies that supports this subgenus, the presence of setae on the abdominal pleurae, is not present in L. chotensis and the other, the absence of the papilla on antennomere $\mathrm{V}$ was impossible to see, because this structure is missing in $L$. chotensis. In addition, L. chotensis differs from the species of $L$.(Tricholateralis) because it has less setae on the tuft of the gonocoxite. On the other hand, the shape of the paramere and the aspect of the basal tuft of setae on the gonocoxite of $L$. chotensis make it looks like some species of the series sanguinaria of L. (Helcocyrtomyia), but the number of apical spines on the gonostyle and the rates between clypeus/head and eye/head length are different. L. chotensis is differentiated from the species of the other two subgenera because its paramere does not bear the two isolated setae. Hence, this new taxon is considered as an isolated species in Lutzomyia, perhaps belonging to a new subgenus, phylogenetically situated between L. (Helcocyrtomyia) and the ancestor of the other subgenera, according to GaLATI's (1995) classification.

Lutzomyia chotensis also looks like some species of Sciopemyia Barretto, 1962 but it may be distinguished by the presence of ventrocervical sensillae, absence of setae on the anterior edge of the katepisternum and the longer labrumepipharynx.

Etymology. The name L. chotensis refers to the type locality.

\section{REFERENCES}

Barretto, M. P. 1962. Novos subgêneros de Lutzomyia França, 1924 (Diptera, Psychodidae, subfamília Phlebotominae). Revista do Instituto de Medicina Tropical de São Paulo 4(2): 91-100.

Cáceres, A. G.; E. A. B. Galati; F. Le Pont \& C. Velásquez. 1995. La fauna flebotomica (Diptera: Psychodidae) de tres provincias de la Region Nor Oriental del Marañon, Peru. Revista da Sociedade Brasileira de Medicina Tropical 28: 215-21.

Cerqueira, N. C. 1943. Novo meio para a montagem de pequenos insetos em lâminas. Memórias do Instituto Oswaldo Cruz 39: 37-41.

Forattini, O. P. 1973. Entomologia Médica. IV. Psychodidae. Phlebotominae. Leishmanioses. Bartonelose. São Paulo, Edgard Blücher Ltda., $658 \mathrm{p}$.

Galati, E. A. B. 1995. Phylogenetic systematics of Phlebotominae (Diptera, Psychodidae) with emphasis on American groups. Boletín de la Dirección de Malariología y Saneamiento Ambiental 35(Supl. 1): 133-142.

Galati, E. A. B. \& A. G. Cáceres. 1994. Descrição de Lutzomyia pallidithorax, sp. n. e de Lutzomyia castanea, sp. n. do Peru e análise cladística das séries do subgênero Helcocyrtomyia Barretto (Diptera, Psychodidae). Revista Brasileira de Entomologia 38(2): 471488.

Galati, E. A. B.; A. G. Cáceres \& F. Le Pont. 1995a. Description of Lutzomyia (Pifanomyia) robusta, n. sp. (Diptera, Psychodidae, Phlebotominae) from Peruvian Equadorean interandean areas. Revista de Saúde Pública 29: 89-99.

Galati, E. A. B.; A. G. Cáceres \& F. Le Pont. 1995b. Descrição de duas espécies novas de Phlebotominae (Diptera, Psychodidae) e considerações sobre a composição de Pifanomyia Ortiz \& Scorza. Revista Brasileira de Entomologia 39: 431-46.

Lewis, D. J.; D. G. Young; G. B. Fairchild \& D. M. Minter. 1977. Proposals for a stable classification of Phlebotomine sandflies (Diptera: Psychodidae). Systematic Entomology 2: 319-332.

Martins, A. V.; P. Williams \& A. L. Falcão. 1978. American Sand Flies. 
Rio de Janeiro, Academia Brasileira de Ciências, 195 p.

McAlpine, J. F. 1981. Morphology and terminology - Adults. p. 9-63. In: J. F. MCAlpine; B. V. Peterson; G. E. Shewell; H. J. Teskey; J. R. Vockeroth \& D. M. Wood. 1981. Manual of Nearctic Diptera. Ottawa, Research Branch Agriculture Canada, Monography 27,Vol. 1.

Sudia, W. A. \& R. W. Chamberlain. 1962. Battery-operated light trap: an improved model. Mosquito News 22 (2): 126-129.

THEODOR, O. 1948. Classification of the Old World species of the subfamily
Phlebotominae (Diptera, Psychodidae). Bulletin of Entomological Research 39: 85-115.

ThEODOR, O. 1965. On the classification of American Phlebotominae. Journal of Medical Entomology 2(2): 171-197.

Young, D. G. \& M. A. Duncan. 1994. Guide to the identification and geographic distribution of Lutzomyia sand flies in Mexico, the West Indies, Central and South America (Diptera: Psychodidae). Memoirs of the American Entomological Institute, 54: 1-881. 